\title{
On Exports and Economic Growth: Revisiting Export-Led Growth Hypothesis Including North- South Divide
}

\author{
Suraj Sharma1 ${ }^{10}$ \\ ${ }^{1}$ Department of Economics, S.M. College, Chandausi \\ (M.J.P. Rohilkhand University, Bareilly, Uttar Pradesh, India) \\ * Corresponding author: surajsharma1903@gmail.com
}

\begin{abstract}
Article History
Received 2021-11-06

Revised 2022-01-05

Accepted 2022-01-10

Published 2022-01-13
\end{abstract}

\section{Keywords}

Export-led growth

Panel cointegration

FM-OLS

DOLS
Objective: The purpose of the present study is to revisit the exportled growth hypothesis in the wake of globalization. This will help in trade policy decisions and make it possible to standpoint whether the export promotion is a good idea to accelerate economic growth.

Design: The ELG hypothesis is examined for 107 countries through panel data analysis using cointegration and panel regression tests from 1990 to 2018. The study finds strong support for the long-run relationship between exports and gross domestic product and the export-led growth hypothesis in a two-variable regression framework.

Findings: It is evident from the long-run coefficient of dynamic ordinary least squared that a 1.0 percent increase in real exports increases the real gross domestic product by 0.53 percent. The long-run coefficient of real exports for the Global South (0.55) is found higher than that of the Global North (0.51), which indicates that in the wave of globalization, the evidence of export-led growth hypothesis is stronger for comparatively poor Global South than the richer Global North.

Practical Implications: The results indicate implications for export promotion policy in the Global South countries to accelerate economic growth and increase real gross domestic product.

Originality: The study is the first to explore the ELG hypothesis using a big pool of 107 countries, including the global north-south divide. 


\section{Introduction}

In the past and even in recent years, scholars have shown great interest in testing the export-led growth (ELG) hypothesis using cross-sectional, time series, and longitudinal data for developed, developing, and underdeveloped countries (Balassa, 1978; Darrat, 1987; Emery, 1967; Giles \& Williams, 2000a; 2000b; Mao, Yao \& Zou, 2019; Singh, 2010; Tang \& Abosedra, 2019). This paper provides insights into the ELG hypothesis, keeping some basic hypotheses in mind and using advanced statistical methods for a large panel of 107 countries of the world and having a recent time dimension from 1990 to 2018. The study is the first in itself, using such a large panel for testing the ELG hypothesis and giving additional statistical evidence for support of ELG hypothesis separately for global South and global north countries of the world. To capture the role of exports in economic growth from the late twentieth century to the present day, it is important to divide the panel of countries into the global North and South. ${ }^{1}$ The global north-south divide splits the globe into advanced and developed north pole countries and least underdeveloped or developing south pole countries.

First, the study hypothesizes that an increase in exports of goods and services leads to an increase in the gross domestic product (GDP) for sample pooled data of 107 countries. The study hypothesizes that the ELG hypothesis for global north countries is significant because they are comparatively prosperous than their southern counterparts. One possible hypothesis is whether the ELG hypothesis is significant for global south countries, first, because this study includes a dataset from the late twentieth century, i.e., 1990, and many global south economies were from then the part of the globalized world economy (Dados \& Connell, 2012). Secondly, with the collapse of the Soviet Union in 1991, globalization spread its boundaries worldwide. The establishment of the World Trade Organization (WTO) in 1995 encouraged nations to form free trade unions and increase the trade volume of goods and services and intellectual property. The success of globalization and increased international trade is visible through the increased number of members of WTO that reached 164, including China. These 164 member countries constitute 98.0 percent of the total international trade (World Trade Organization, 2021).

According to the World Development Indicators database, as far as global trade is concerned, it stood up at 27.0 percent of world GDP in 1970, which increased to 39.0 percent in 1990 and further to 59.0 percent in 2018, all because of increased international cooperation and globalization. The trend of trade GDP ratio shows that both low-income and high-income economies have high proportions of openness compared to middleincome economies. It indicates middle-income economies somehow manage economic growth without

\footnotetext{
${ }^{1}$ It is evident that this divide is based on level of economic development and wealth, moreover, there is also a clear geographical divide between the rich Global North and the poor Global South which provides an imaginary line called 'The Brandt line.' This divides the world into two parts as countries situated on northern and southern hemisphere. However, there are many countries in the global south which are comparatively rich than their counterpart south economies and even at par with some global north economies. Additionally, there are some exception economies which geographically lies in the Global South but are actually from the Global North. The global south consists whole of Asia, Caribbean, Central and South America, Mexico, Africa and Middle East except Japan, Hong Kong, Macao, Singapore, South Korea and Taiwan from Asia, and Israel from Middle East. Australia and the New Zealand being in southern hemisphere comes in global north.
} 
opening their economies to a much extent for trade, particularly for upper-middle-income economies (see Figure 1).

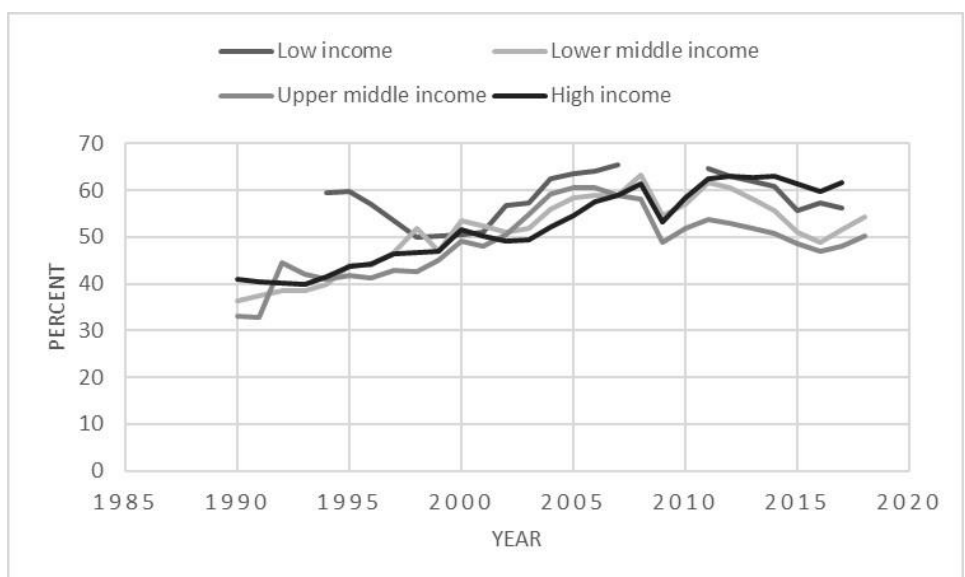

Figure 1: Trend of trade GDP ratio for different income economies (1990-2018)

\section{Source: World Development Indicator, World Bank Group}

Opening the economy for trade is not enough for economic growth. A country should have a competitive production surplus to export (Leff, 1969), and this benefit from trade can be seen through export GDP ratios of different economies. As far as the world economy is concerned, the export GDP ratio stood up at 13.0 percent in 1970, increasing to 19.0 percent and 30.0 percent in 1990 and 2018, respectively. Export GDP ratio shows a similar trend to trade GDP ratio. The export GDP ratio for high-income economies is high compared to low-income and middle-income economies. The export GDP ratio is the least for low-income economies throughout the last two decades. Low-income economies may be susceptible to trade disadvantages as these economies have a comparatively high trade GDP ratio but a meager export GDP ratio (see Figure 2). However, the annual growth rate of exports shows a positive and upward trend for lower-middle-income economies and a downward trend for high-income economies (see Figure 3).

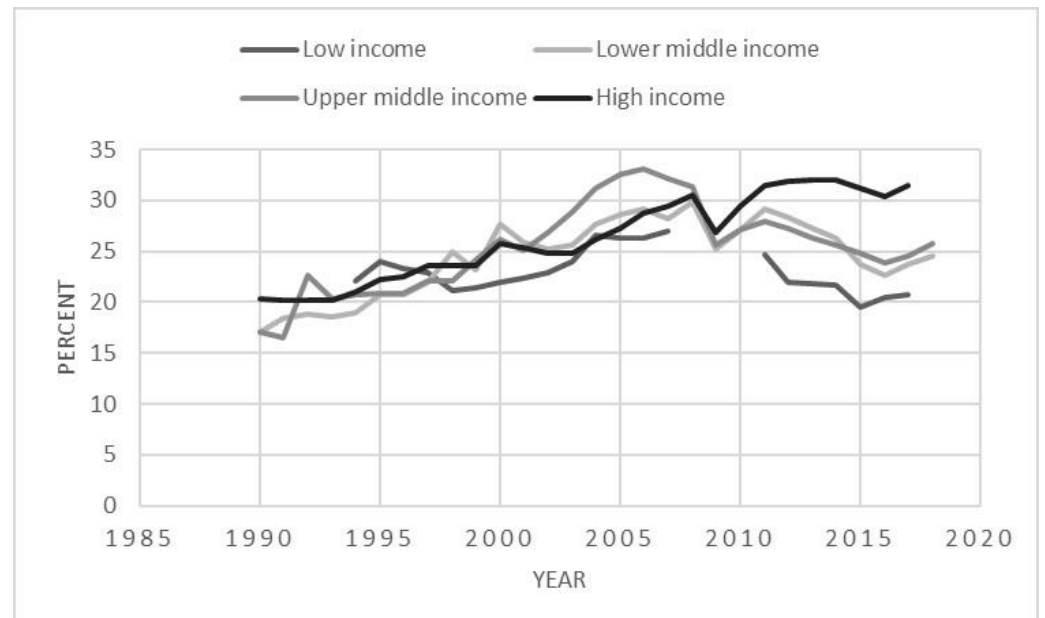

Figure 2: Trend of export GDP ratio for different income economies (1990-2018)

Source: World Development Indicator, World Bank Group 


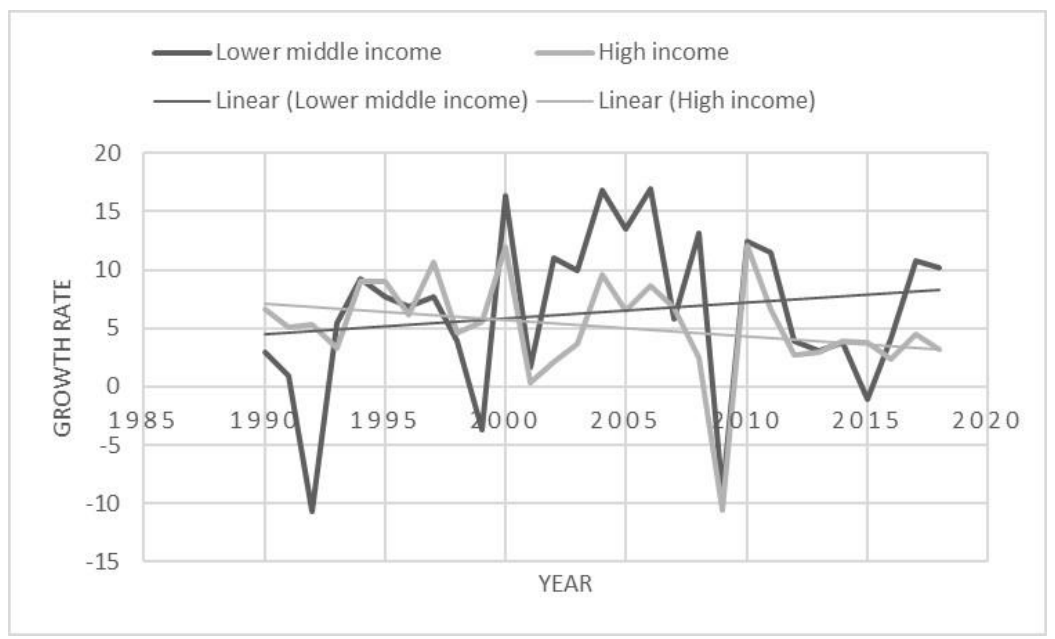

Figure 3: Trend of annual export growth rates (\%) for different income economies (1990-2018)

Source: Based on Author's calculation using World Development Indicator, World Bank Group

For the period 1990 to 2018, the United States of America (USA) had the highest mean GDP and mean exports in study sample of 107 nations. While Japan had the second largest mean GDP during the time, its mean exports were lower than economies such as Germany and China. With the exception of a few advanced economies such as Japan and the United States, developing economies such as Brazil, and low-income economies on the African continent, the majority of economies, including France, the United Kingdom (U.K.), Italy, Canada, and the Netherlands, are inclined to a high proportion of exports in GDP (see Figure 4). As level variables are transformed to natural logs, the distribution shows that most economies are on a 45-degree line of equality, with an equal proportionate change in GDP and exports (see Figure 5).

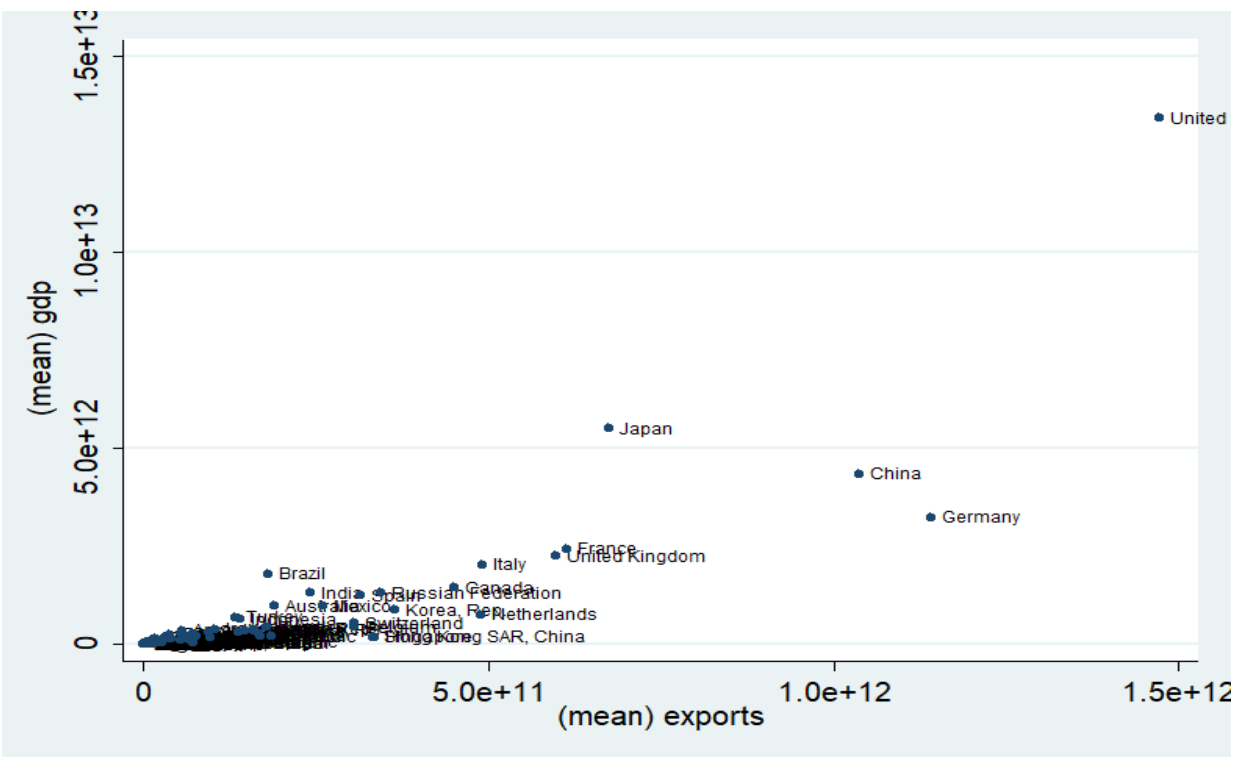

Figure 4: Scatterplot of mean (GDP) and mean (Exports)

Source: Based on Author's calculation using World Development Indicator, World Bank Group 


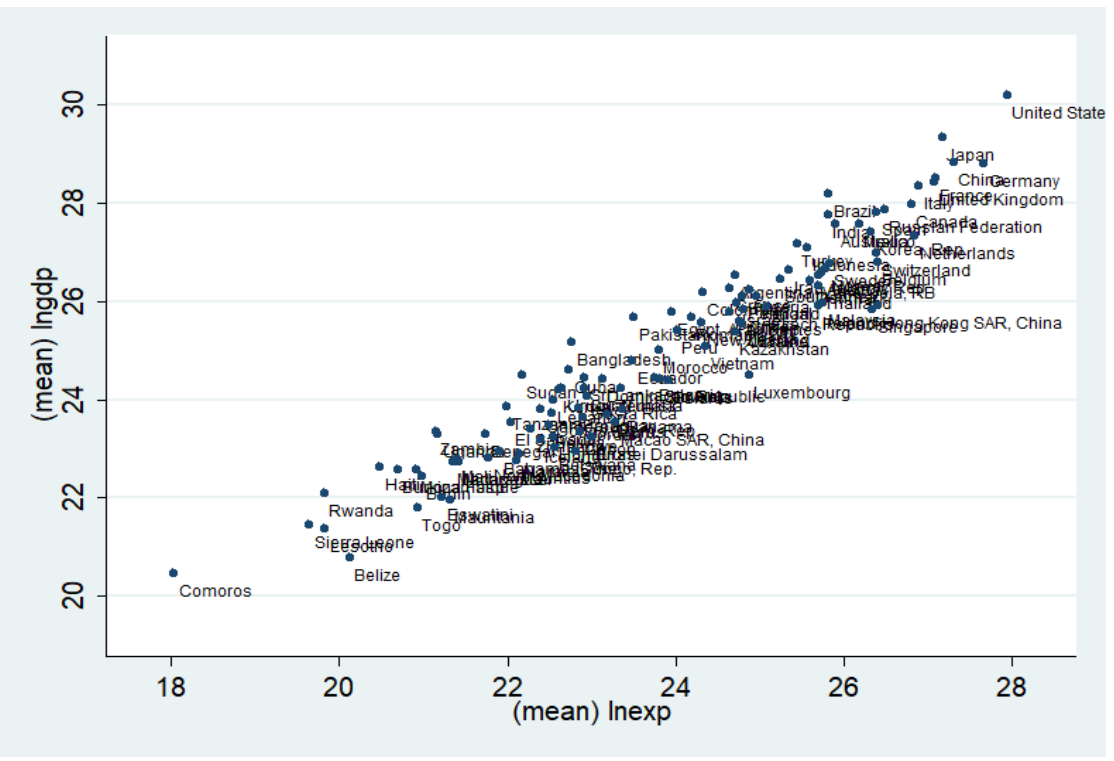

Figure 5: Scatterplot of mean (ln GDP) and mean (ln Exports)

Source: Based on Author's calculation using World Development Indicator, World Bank Group

The scatter plot on the mean log of GDP and mean log of exports for Global South is much more uniform than the scatter plot of Global North (see Figures 6 and 7). The plot for Global South is very similar to the pooled data plot discussed earlier (see Figure 5). In Global North, economies like Germany, Netherland, Switzerland, Belgium, Hong Kong, Singapore, Luxembourg, Macao are more open than other countries of Global North, and these economies are much more export-oriented than others. This primary analysis shows a need to capture the ELG hypothesis from the global north-south point of view so that the role of exports in economic growth can be re-examined in the present scenario of a more globalized world and comparatively poor Global South.

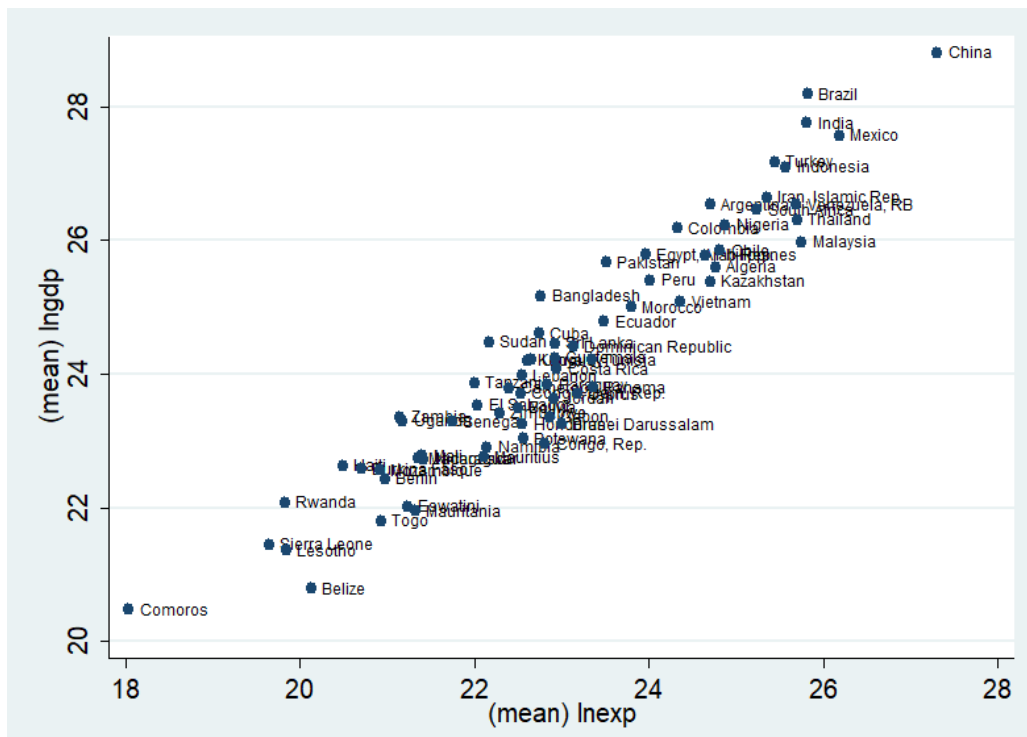

Figure 6: Scatterplot of the mean (In GDP) and mean (In Exports) for Global South

Source: Based on Author's calculation using World Development Indicator, World Bank Group 


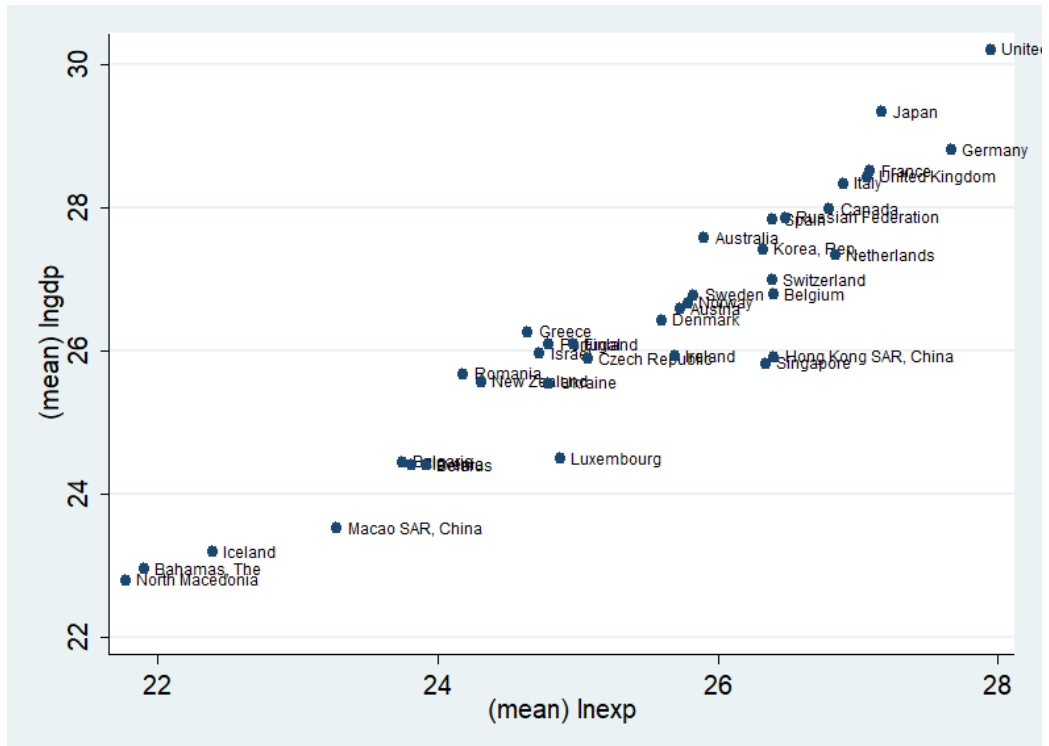

Figure 7: Scatterplot of the mean (In GDP) and mean (lnExports) for Global North

Source: Based on Author's calculation using World Development Indicator, World Bank Group

\section{Literature Review}

\section{ELG Hypothesis Revisited}

Earlier works have explained the role of exports in economic growth by counting the advantages of export promotion policies. First, exports are not only part of the production function, but it creates positive externalities by creating working opportunities in domestic industries/markets (Abosedra \& Tang, 2019); second, it brings new technologies and skills by increased international cooperation (Grossman \& Helpman, 1991), third, open trade policies not only help in economic growth but also enable to reduce poverty, improve productivity and innovate (World Bank, 2018), fourth, increased international collaboration and identifying export activities as part of country's economic agenda helps in creating jobs and economic growth (Katz \& Istrate, 2011) and most importantly, export-oriented industrialization which has been stabilized in studies like Keesing (1967), Krueger (1975), Bhagwati (1982), Srinivasan (1985), Chow (1987).

Many studies have found strong evidence of export-led growth, including Emery (1967), Severn (1968), Balassa (1978), Feder (1983), Heitger (1987), Ram (1987), Fosu (1990), Sengupta (1991), Khan and Saqib (1993), Lussier (1993), Lee and Cole (1994), Van den Berg and Schmidt (1994), Begum and Shamsuddin (1998), Giles and Williams (2000a; 2000b), Love and Chandra (2005), Furuoka (2007), Dash (2009), Singh (2010), He and Zhang (2010), Tiwari (2011), Hye, Wizarat and Lau (2013), Ee (2016), Tang and Tan (2015), Ahmad, Draz and Yang (2018), Ali and Li (2018), Mao et al. (2019), Tang and Abosedra (2019), Felipe and Lanzafame (2020). Here, a study from China supported ELG by examining the causality between exports and total factor productivity. The study found growth is mainly supported by the supply-side perspective increasing the economy's production capacity (He \& Zhang, 2010). Another study (Ee, 2016) found support for ELG for Sub-Saharan African countries from 1985 to 2014. It opined a long-run relationship between exports and growth using panel regression with significant regressors like investment and government expenditure. Mao et al. (2019) found that the faster growth productivity in the export sector led to higher economic growth under a fixed exchange rate regime. Tang and Abosedra (2019) took a sample of 21 Asian economies and found ELG valid from 2010 to 2016. Logistics sector performance was found to affect export growth and economic growth significantly. 
Recently, Felipe and Lanzafame (2020) showed that China's growth trajectory, since the early 1980s, has been associated with the consistent and significant growth of its exports.

However, studies like Syron and Walsh (1968), Maizels (1968), and Kravis (1970) found the nature of exports as a determining factor of whether an economy will be benefited from export growth or not. The results revealed that export diversification, particularly to manufactured goods, helps stimulate economic growth through increased productivity in the domestic sectors of less developed countries. According to Syron and Walsh (1968), growth in exports positively affected real gross national product (GNP) per capita, but the commodity of exports decided the magnitude of benefit as evidence of the differing impact of exports on least and most developed economies were visible. It is found that the relationship between trade and growth cannot be generalized. External demand for exports and internal factors strengthen the growth path (Kravis, 1970).

Additionally, studies like Michaely (1977), Tyler (1981), Kavoussi (1984), Balassa (1985), Ram (1985), Moschos (1989) supported the ELG hypothesis conditioning an income threshold and indicating that counties that reach a minimum level of national income get more benefits from export growth. Like Michaely (1977) found, export growth is positively associated with economic growth for more developed economies and not at all for least developed ones. Kavoussi (1984) explained that export expansion is positively associated with economic growth by positively influencing total factor productivity for developing nations, and gains persist with the shift from primary to manufactured goods as the country's income increases. Similarly, Balassa (1985) found that outwardoriented trade policy with product diversification towards manufactured goods positively affects the growth performance of developing economies. Ram (1985) opined export performance affects economic growth, and this association gets more robust in times of strain on the balance of payment.

There is considerable literature available which either weakly support the ELG hypothesis or reject it significantly, and among these, some important studies are like Heller and Porter (1978), Jung and Marshall (1985), Darrat (1987), Colombatto (1990), Kugler (1991), Afxentiou and Serletis (1991), Serletis (1992), Sheehey (1993), Greenaway and Sapsford (1994), Jin (1995), Henriques and Sadorsky (1996), Al-Yousif (1997), Islam (1998), Shan and Sun (1998), Dhawan and Biswal (1999), Sharma and Panagiotidis (2005). Among these, Heller and Porter (1978) found export-led growth visible for only some comparatively rich economies with low export shares of output. Jung and Marshall (1985) found that only 4 out of 37 developing nations showed exports causing economic growth, and, in many cases, exports reducing growth has been found.

Darrat (1987) examined a sample of the then four newly industrialized countries (NIC) of Asia and found causality from export growth to economic growth rejected for 3 out of 4 economies. However, a positive association was found between exports and economic growth. Kugler (1991) examined six industrialized economies to test ELG and found only 2 (France and West Germany) out of 6 countries (including the USA) showed a long-run relationship between exports and GDP. Studies like Afxentiou and Serletis (1991) for 16 industrialized countries, Serletis (1992) for Canada, Sheehey (1993) for 65 semi-industrialized countries, Greenaway and Sapsford (1994), Jin (1995) for four little tigers of Asia, Henriques and Sadorsky (1996) for Canada, Al-Yousif (1997) for four Arab Gulf nations, Islam (1998) for 15 NICs of Asia, Shan and Sun (1998) for China, Dhawan, and Biswal (1999), Sharma and Panagiotidis (2005) for India showed only short-run or bidirectional causality between exports and economic growth which makes ELG hypothesis weaker. Tang, Lai, and Ozturk (2015) and Abosedra and Tang (2019) have also found the ELG hypothesis unstable.

These studies reviewed so far have used cross-section, time series, and longitudinal data and cover almost all world economies. It can be inferred from earlier works that, in general, the ELG hypothesis is somewhat weak, if not rejected, for low-income or less developed economies, and there also exists a threshold income for exportled growth. In the 1960s and 1970s, most studies used two variable frameworks and simple regression correlation techniques to test the ELG hypothesis. Still, later studies used multivariate frameworks including 
domestic and foreign investment, labor force, foreign exchange reserves, the balance of payment (BoP), and other variables and used advanced econometric techniques like cointegration, causality tests, etc.

The study found some relevant dimensions to extend the earlier works. First, this study covers a pool of all relevant nations adding up to 107 countries of the world and years from 1990 to 2018 (the latest available data). As no other study has used such a big pool of countries earlier, it would be giving new insights on ELG. Second, the period for the study is being selected in the wake of globalization to capture the relevance of the ELG hypothesis in the present scenario. The findings will help in trade policy decisions and make it possible to standpoint whether the export promotion is a good idea to accelerate economic growth. Third, as earlier literature points out towards a threshold income effect of exports on economic growth, this study divides the sample of 107 countries into two parts, i.e., the Global North (comparatively rich) and the Global South (comparatively poor). This will help both developed and developing nations formulate future trade policy decisions when international cooperation increases rapidly. Fourth, the study employs the latest available panel econometric techniques to test ELG hypotheses such as panel unit root tests followed by panel cointegration tests and, finally, practical panel regression tests.

\section{Data and Methodology}

The data for the study has been drawn from World Development Indicators (WDI) of the World Bank Group. This paper is based on panel data of the world's major 107 countries (see appendix) to analyze the export-led growth hypothesis (ELGH) from 1990 to 2018. The data on the real gross domestic product (real GDP) and real exports of goods and services are in constant of 2010 US dollar. Further to test ELGH for global South and global north countries, two separate pooled panel analyses have been carried out with the same dimensions. A total of 3103 observations has been analyzed at the world level for 107 countries, while 2030 observations (70 countries) are from the global South and 1073 observation (37 countires) are from the global North. The study uses a simple two-variable regression framework as follows;

$$
\text { real } G D P=f(\text { real exports })
$$

\section{Panel Unit Root Tests}

Panel unit root tests are preconditions for panel co-integration tests. The study employs both the first- and second-generation panel unit root tests to avoid misleading results and report statistics based on constant (intercept) only and constant and trend. The panel unit root test and statistic can be drawn from the following regression model;

$$
\mathcal{Y}_{i t}=\rho \mathcal{Y}_{i, t-1}+Z_{i t}^{\prime} \mathcal{Y}_{i}+\varepsilon_{i t}
$$

Where $i=1, \ldots, \mathrm{N}$ indexes panel; $t=1, \ldots, \mathrm{T}_{i}$ indexes time; $\mathcal{Y}_{i t}$ is the variable being tested for unit root and $\varepsilon_{i t}$ is the white noise error term. The term $Z_{i t}^{\prime} \mathcal{Y}_{i}$ allows for panel specific means or means and trends or nothing based on the value of $\mathcal{Z}_{i t}^{\prime}$. Panel unit root tests use the null hypothesis of $H_{0}: \rho_{i}=1$ for all $i$ against the alternative of $\mathrm{H}_{1}: \rho_{i}<1$. Cross-sectional means have been removed before testing unit root tests.

First, the unit root test developed by Harris-Tzavalis (1999) has been used, which assumes a fixed T or time dimension and a greater $\mathrm{N}$ or number of panels. It assumes a common autoregressive parameter for all panels or cross-sectional independence, which is a weakness of first-generation panel unit root tests like the HT test.

Second, for this purpose, one of the second-generation tests of panel unit root, i.e., the Im-Pesaran-Shin (2003) test, has been used. It relaxes the assumption of cross-sectional independence and allows for more precision in defining the stationarity of the variable. It uses a set of Dickey-Fuller regressions where errors may have heterogenous variances across panels. Similarly, the ADF fisher type unit root test has also been used, which 
performs a separate unit root ADF test on each panel and combines each p-value generated in the process to obtain an overall statistic for the panel unit root test. Here, the study has used the inverse normal Z statistic, which offers the best result suggested by Choi (2001).

\section{Panel Co-Integration Tests}

The study uses panel co-integration tests if all the variables used in the model are stationary at first difference. If panels are stationary at levels, then a simple pooled, fixed, or random effect model can be applied. For this purpose, the study uses two different panel co-integration tests suggested by Pedroni (1999, 2004) and Westerlund (2005) to confirm the long-run relationship between exports and GDP. Both the tests have a null hypothesis of no co-integration. Both the constant only and constant and trend estimations of co-integration are reported for precise results. The panel co-integration tests are based on the following regression;

$$
y_{i t}=x_{i t}^{\prime} \beta_{i}+z_{i t}^{\prime} y_{i}+\varepsilon_{i t}
$$

Here $\mathcal{X}_{i t}^{\prime}$ are covariates and $\beta_{i}$ denotes the cointegrating vector. In panel co-integration, it is to test whether $\varepsilon_{i t}$ is non-stationary or not. The residuals are estimated using Eq. (3), and to get DF t, DF regression is fitted as follows;

$$
\hat{\varepsilon}_{i t}=\rho \hat{\varepsilon}_{i, t-1}+v_{i t}
$$

Where $\rho$ is the panel-specific autoregressive term and test whether the coefficient $\rho$ is 1 . The equation for the PP t-test is as follows;

$$
\hat{\varepsilon}_{i t}=\rho_{i} \hat{\varepsilon}_{i, t-1}+v_{i t}
$$

The PP t-test tests whether $\rho_{i}$ s are 1 or not.

The augmented Dickey-Fuller (ADF) $t$ is computed using the following regression, which uses additional lags;

$$
\hat{\varepsilon}_{i t}=\rho_{i} \hat{\varepsilon}_{i, t-1}+\sum_{j=1}^{p} \rho_{i j} \Delta \hat{\varepsilon}_{i, t-j}+v_{i t}^{*}
$$

Where $\triangle \hat{\varepsilon}_{i, t-j}$ is the $\mathrm{jth}$ lag of the first difference of $\hat{\varepsilon}_{i t}$ and $\mathrm{j}=1, \ldots, \mathrm{p}$, where $\mathrm{p}$ is the number of lag differences.

The test suggested by Pedroni $(1999,2004)$ produces two types of statistics, i.e., within (panel) and between (group). The study computes PP and ADF t statistics for each type of test. The Pedroni test is somewhat better than Kao (1999) as it considers heterogeneity in using panel-specific parameters. On the other hand, Westerlund (2005) suggested a panel co-integration test based on variance ratio (VR). The test statistics are computed using the ratio of variances of the predicted residuals of Eq. (3). The test computes four different statistics, of which two are based on cross-sectional units, and two are based on the panel as a whole.

\section{Co-Integration Estimations}

The panel co-integration tests only indicate the presence of a long-run relationship between regressand and regressors. Still, it cannot estimate the exact long-run relationship and its direction. For this purpose, fully modified OLS (FM-OLS) and dynamic OLS (DOLS) can be used to estimate single equation estimators for a long-run relationship between cointegrated variables.

As evident from the study of Kao and Chiang (2001), the OLS and FM-OLS estimates are not consistent for a homogenous and heterogenous panel, while DOLS perform better than OLS and FM-OLS in all cases of 
homogenous and heterogenous panels by adding optimal leads and lags to the regression. This reduces the bias of the DOLS estimates.

\section{Empirical Findings}

\section{Panel Unit Root Results}

To begin with panel data analysis testing ELGH and capturing the long-run relationship between GDP and exports for a panel of 107 countries, the study first employs Harris-Tzavalis (1999) panel unit root test on natural logs of variables which confirms that both real GDP and real exports have a unit root at levels for the study period. The results of unit root at levels are consistent for both constant (intercept) and constant and trend regressions. However, all of them become stationary at first difference.

The unit root test results for the global South and global north are consistent with the results of the pooled panel, and variables are I (1) for each series. The results of the panel unit root test suggested by Im et al. (2003) and ADF Fisher type are consistent with the results of Harris-Tzavalis (1999) (see table 1) and confirm that both real GDP and real exports are integrated of order one or I (1).

Table 1- Unit root tests

\begin{tabular}{|c|c|c|c|c|c|c|}
\hline \multirow[t]{2}{*}{ Variables (Natural log) } & \multicolumn{2}{|c|}{$\begin{array}{l}\text { Harris-Travalis } \\
\text { (z value) }\end{array}$} & \multicolumn{2}{|c|}{$\begin{array}{l}\text { Im-Pesaran-Shin } \\
(t \text {-bar }\end{array}$} & \multicolumn{2}{|c|}{$\begin{array}{l}\text { ADF-Fisher } \\
\text { (inverse normal Z) }\end{array}$} \\
\hline & Levels & $\mathrm{I}(1)$ & Levels & $\mathrm{I}(1)$ & Levels & $\mathrm{I}(1)$ \\
\hline \multicolumn{7}{|l|}{ Constant } \\
\hline \multicolumn{7}{|c|}{ Pooled data (Countries $=107, T=29)$} \\
\hline GDP per capita & 4.533 & $-59.799^{* * *}$ & -0.474 & $-4.033^{* * *}$ & 8.672 & $-22.261^{* * *}$ \\
\hline Exports & 2.288 & $-81.125^{* * *}$ & -1.346 & $-4.783^{* * *}$ & 1.224 & $-26.655^{* * *}$ \\
\hline \multicolumn{7}{|c|}{ Global South (Countries $=70)$} \\
\hline GDP per capita & 2.727 & $-55.960^{* * *}$ & -0.219 & $-4.197^{* * *}$ & 9.130 & $-17.583^{* * *}$ \\
\hline Exports & 2.1840 & $-68.016^{* * *}$ & -1.307 & $-4.812^{* * *}$ & 1.571 & $-20.617^{* * *}$ \\
\hline \multicolumn{7}{|c|}{ Global north (Countries $=37)$} \\
\hline GDP per capita & 2.136 & $-21.696^{* * *}$ & -0.956 & $-3.724^{* * *}$ & 2.211 & $-13.671^{* * *}$ \\
\hline Exports & 0.2996 & $-38.297^{* * *}$ & -1.419 & $-4.728^{* * *}$ & -0.079 & $-16.968^{* * *}$ \\
\hline \multicolumn{7}{|c|}{ Constant and trend } \\
\hline \multicolumn{7}{|c|}{ Pooled data (Countries $=107, T=29)$} \\
\hline GDP per capita & 3.605 & $-24.165^{* * *}$ & -2.125 & $-4.186^{* * *}$ & $-2.566^{* *}$ & $-17.234^{* * *}$ \\
\hline Exports & 0.717 & $-40.849^{* * *}$ & -1.978 & $-5.042^{* * *}$ & 1.381 & $-24.084^{* * *}$ \\
\hline \multicolumn{7}{|c|}{ Global South (Countries $=70)$} \\
\hline GDP per capita & 1.501 & $-25.382^{* * *}$ & -2.178 & $-4.380^{* * *}$ & $-2.418^{* *}$ & $-13.265^{* * *}$ \\
\hline Exports & 0.9975 & $-34.739^{* * *}$ & -1.883 & $-5.078^{* * *}$ & 1.394 & $-18.381^{* * *}$ \\
\hline \multicolumn{7}{|c|}{ Global north (Countries $=37$ ) } \\
\hline GDP per capita & 2.986 & $-6.418^{* * *}$ & -2.026 & $-3.820^{* * *}$ & -1.039 & $-11.063^{* * *}$ \\
\hline Exports & -0.6881 & $-17.517^{* * *}$ & -2.158 & $-4.973^{* * *}$ & 0.431 & $-15.674^{* * *}$ \\
\hline
\end{tabular}

Note: ${ }^{* *}$ and $* * *$ denote 0.05 and 0.01 level of significance, respectively. The optimum lag length has been chosen using AIC as 1 for the above unit root tests.

\section{Panel Cointegration Results}

As evident from unit root tests, both real GDP and real exports integrated order one. Panel cointegration tests can be applied to the equation above (see table 2). Model having real GDP as regressand and real exports as 
regressor is used for cointegration test. Pedroni's cointegration test statistics indicate cointegration at the 0.01 level, which is visible for constant and trend estimations. The same is true for the global South and global north panels. The result of Pedroni's cointegration indicates a long-run relationship between the variables.

Table 2. Pedroni's panel cointegration test

\begin{tabular}{lll}
\hline real GDP $=\boldsymbol{f}(\boldsymbol{r e a l}$ exports $)$ & Constant & Constant and trend \\
\hline Pooled data & & \\
\hline Panel PP stat & -1.352 & $-2.758^{* * *}$ \\
Panel ADF stat & -1.06 & $-3.738^{* * *}$ \\
Group PP stat & $-7.208^{* * *}$ & $-10.3^{* * *}$ \\
Group ADF stat & $-9.425^{* * *}$ & $-13.72^{* * *}$ \\
\hline Global South & & \\
\hline Panel PP stat & -0.2129 & $-2.65^{* * *}$ \\
Panel ADF stat & 0.3101 & $-3.078^{* * *}$ \\
Group PP stat & 0.6459 & $-1.659^{*}$ \\
Group ADF stat & -0.7035 & $-4.215^{* * *}$ \\
\hline Global North & & \\
\hline Panel PP stat & $-2.773^{* * *}$ & $-1.716^{*}$ \\
Panel ADF stat & $-3.514^{* * *}$ & $-2.736^{* * *}$ \\
Group PP stat & $-2.776^{* * *}$ & -1.1 \\
Group ADF stat & $-4.28^{* * *}$ & $-2.767^{* * *}$ \\
\hline
\end{tabular}

Note: ${ }^{*},{ }^{* *}$ and ${ }^{* * *}$ denote $0.10,0.05$ and 0.01 level of significance, respectively. Optimum lag length and leads have been chosen using AIC as 2 for the above cointegration test.

The study next employs Westerlund's cointegration test to confirm the long-run relationship between real GDP and real exports for pooled data. The test results suggest that there is cointegration between real GDP and real exports for the study period for a model constant and trend. The result of cointegration tests indicates that the global north panel exhibits a clear long-run relationship which is evident from the constant and constant and trend significant estimations. However, the same is not true for the global South.

Table 3. Westerlund's ECM panel cointegration test

\begin{tabular}{lll}
\hline real GDP $=\boldsymbol{f}(\boldsymbol{r e a l}$ exports $)$ & Constant & Constant and trend \\
\hline Pooled data & & \\
\hline $\mathrm{Gt}$ & 0.345 & $-9.692^{* * *}$ \\
$\mathrm{Ga}$ & 1.786 & 5.961 \\
$\mathrm{Pt}$ & 1.782 & $-5.587^{* * *}$ \\
$\mathrm{~Pa}$ & -0.933 & $-1.848^{* *}$ \\
\hline Global South & & \\
\hline $\mathrm{Gt}$ & 3.888 & $-8.775^{* * *}$ \\
$\mathrm{Ga}$ & 3.684 & 4.340 \\
$\mathrm{Pt}$ & 2.465 & $-1.659^{* *}$ \\
$\mathrm{~Pa}$ & 0.276 & 0.551 \\
\hline Global North & & \\
\hline $\mathrm{Gt}$ & $-4.761^{* * *}$ & $-4.413^{* * *}$ \\
$\mathrm{Ga}$ & $-2.029^{* *}$ & 4.167 \\
$\mathrm{Pt}$ & $-3.161^{* * *}$ & $-7.149^{* * *}$ \\
$\mathrm{~Pa}$ & $-5.444^{* * *}$ & $-4.116^{* * *}$ \\
\hline
\end{tabular}


Note: *, ** and *** denote 0.10, 0.05 and 0.01 level of significance, respectively. Optimum lag length and leads have been chosen using AIC for the above cointegration test. $z$-values have been shown to test the null hypotheses of no evidence of cointegration of at least one of the cross-sectional units (Gt and $\mathrm{Ga}$ ) and as no evidence of cointegration for the panel as a whole (Pt and $\mathrm{Pa}$ ).

\section{Panel Cointegration Estimations Using FM-OLS and DOLS}

The presence of panel cointegration suggested by Pedroni's and Westerlund's cointegration tests leads to the estimate of FM-OLS and DOLS coefficients to know the direction and magnitude of the long-run relationship between real real real GDP and real exports. It is evident from the pooled regression coefficients that for 107 countries panel from the year 1990 to 2018, there is a long-run relationship between real GDP and real exports. The ELG hypothesis is being proved for this large panel. The positive and significant coefficients of FM-OLS and DOLS suggest a long-run linkage between real exports and growth (real GDP). According to FM-OLS and DOLS estimations, a 1.0 percent increase in real exports will increase real GDP by 0.54 percent and 0.53 percent, respectively.

Table 4. Results of Fully Modified OLS and Dynamic OLS estimations

\begin{tabular}{|c|c|c|c|c|c|c|}
\hline \multirow{2}{*}{$\begin{array}{l}\text { Real GDP on Real } \\
\text { Exports }\end{array}$} & \multicolumn{3}{|l|}{ FMOLS } & \multicolumn{3}{|l|}{ DOLS } \\
\hline & Coefficient & t-value & R-squared & Coefficient & t-value & R-squared \\
\hline Pooled data & $\begin{array}{l}0.548201^{* * *} \\
(0.009694)\end{array}$ & 56.55048 & 0.994560 & $\begin{array}{l}0.537967^{* * *} \\
(0.009092)\end{array}$ & 59.17198 & 0.995743 \\
\hline Global South & $\begin{array}{l}0.561662^{* * *} \\
(0.012709)\end{array}$ & 44.19483 & 0.991143 & $\begin{array}{l}0.549100^{* * *} \\
(0.011900)\end{array}$ & 46.14435 & 0.993043 \\
\hline Global North & $\begin{array}{l}0.507626^{* * * *} \\
(0.012823)\end{array}$ & 39.58603 & 0.996744 & $\begin{array}{l}0.505313^{* * * *} \\
(0.012359)\end{array}$ & 40.88727 & 0.997465 \\
\hline
\end{tabular}

Note: $*, * *$, and $* * *$ denote $10 \%, 5 \%$ and $1 \%$ level of significance, respectively. Figures in parentheses are corresponding standard errors. Automatic leads and lags specifications are based on the SIC criterion.

As evident from the long-run coefficients of the Global South and the Global North, the coefficient for Global South is higher than that of the Global North and indicates that the ELG hypothesis is stronger in the Global South comparison to the Global North. For the Global South, the long-run coefficients of FM-OLS and DOLS indicate that a 1.0 percent increase in real exports will increase the real GDP by 0.56 percent and 0.55 percent, respectively. For the Global North, the long-run coefficients of FM-OLS and DOLS are approximately the same i.e., 0.51 .

\section{Conclusion and Policy Implications}

This study examined the export-led growth hypothesis for 107 countries through panel data analysis using unit root tests followed by cointegration and panel regression tests, i.e., FM-OLS and DOLS from 1990 to 2018. The empirical results indicated strong support for the long-run relationship between real exports and real GDP and the export-led growth hypothesis in these countries' two-variable regression framework. It is evident from the long-run coefficient of DOLS that a 1.0 percent increase in real exports increases the real GDP by 0.53 percent. The long-run coefficient of real exports for the Global South (0.55) is found higher than that of the Global North (0.51), which indicates that in the wave of globalization, the evidence of export-led growth hypothesis is stronger for comparatively poor Global South than the richer Global North.

For the pooled sample from 1990 to 2018, this empirical study revealed that an increase in real exports leads to real GDP. In the long run, exports have had a major and favorable impact on domestic production in the Global North and South. In terms of trade GDP and export GDP ratios, the North is more open to international trade than the South; however, the South has benefited more in the last decade of the twentieth 
century due to continuous efforts to reduce trade restrictions and technological advancement (International Monetary Fund, 2001), as evidenced by the DOLS coefficients. Comparatively poor Global South countries have reaped the benefits of increased exports in the late $20^{\text {th }}$ and beginning of the 21 st century to increase real GDP. Increased globalization has benefitted comparatively developing countries more than rich countries. Previous research (Ee, 2016; Felipe \& Lanzafame, 2020; He \& Zhang, 2010; Mao et al., 2019; Tang and Abosedra, 2019) that looked at a sample from the global South provided support for this study. The results indicate implications for export promotion policy in the Global South countries to accelerate economic growth and an increase in the real gross domestic product in the present scenario.

Funding: The author received no financial support for this article's research, authorship, and/or publication.

Acknowledgments: The views expressed in this paper are those of the author and do not reflect the institution's views to which the author is affiliated. I thank my colleagues who provided insights and expertise, which greatly assisted the research. However, any errors are my own and should not tarnish the reputation of esteemed persons from respective institutions.

Conflicts of Interest: The author declared no potential conflicts of interest concerning this article's research, authorship, and/or publication.

\section{References}

Abosedra, S., \& Tang, C.F. (2019). Are exports a reliable source of economic growth in MENA countries? New evidence from the rolling Granger causality method. Empirical Economics, 56, 831-841. https://doi.org/10.1007/s00181-017-1374-7

Afxentiou, P.C., \& Serletis, A. (1991). Exports and GNP Causality in the industrial countries: 1950-1985. Kyklos, 44(2), 167-179. https://doi.org/10.1111/j.1467-6435.1991.tb02095.x

Ahmad, F., Draz, M.U., \& Yang, S.-C. (2018). Causality nexus of exports, FDI and economic growth of the ASEAN5 economies: evidence from panel data analysis. Journal of International Trade and Economic Development, 27(6), 685-700. https://doi.org/10.1080/09638199.2018.1426035

Al-Yousif, Y.K. (1997). Exports and economic growth: Some empirical evidence from the Arab Gulf countries. Applied Economics, 29(6), 693-697. https://doi.org/10.1080/000368497326624

Ali, G., \& Li, Z. (2018). Exports-led growth or growth-led exports in the case of China and Pakistan: An empirical investigation from the ARDL and Granger causality approach. International Trade Journal, 32(3), 294-314. https://doi.org/10.1080/08853908.2017.1379449

Balassa, B. (1978). Exports and economic growth. Journal of Development Economics, 5(2), 181 189. doi:10.1016/0304-3878(78)90006-8

Balassa, B. (1985). Exports, policy choices, and economic growth in developing countries after the 1973 oil shock. Journal of Development Economics, 18(1): 23-35. doi:10.1016/0304-387

Begum, S., \& Shamsuddin, A.F. (1998). Exports and economic growth in Bangladesh. Journal of Development Studies, 35(1), 89-114. doi:10.1080/00220389808422556

Bhagwati, J.N. (1982). Directly Unproductive, Profit-Seeking (DUP) Activities. Journal of Political Economy, 90(5), 988-1002. www.jstor.org/stable/1837129

Choi, I. (2001). Unit root tests for panel data. Journal of International Money and Finance, 20(2), 249-272. https://doi.org/10.1016/S0261-5606(00)00048-6

Chow, P.C. (1987). Causality between export growth and industrial development: Empirical evidence from the NICs. Journal of Development Economics, 26(1), 55-63. https://doi.org/10.1016/0304-3878(87)900514

Colombatto, E. (1990). An Analysis of Exports and Growth in LDCs. Kyklos, 43(4), 579597. doi:10.1111/j.1467-6435.1990.tb02238.x 
Dados, N., \& Connell, R. (2012). The Global South. Contexts, 11(1), 12-13. doi:10.1177/1536504212436479

Darrat, A.F. (1987). Are exports an engine of growth? Another look at the evidence. Applied Economics, 19(2), 277-283. doi:10.1080/00036848700000102

Dash, R.K. (2009). Revisited Export-Led Growth Hypothesis: An Empirical Study on India. South Asia Economic Journal, 10(2), 305-324. https://doi.org/10.1177/139156140901000203

Dhawan, U., \& Biswal, B. (1999). Re-examining export-led growth hypothesis: a multivariate cointegration analysis for India. Applied Economics, 31(4), 525-530. https://doi.org/10.1080/000368499324246

Ee, C.Y. (2016). Export-Led Growth Hypothesis: Empirical Evidence from Selected Sub-Saharan African Countries. Procedia Economics and Finance, 35, 232-240. https://doi.org/10.1016/S2212-5671(16)000290

Emery, R.F. (1967). The Relation of Exports and Economic Growth. Ky/klos, 20(4), 470-486. doi:10.1111/j.1467-6435.1967.tb00859.x

Feder, G. (1983). On exports and economic growth. Journal of Development Economics, 12(1-2), 59_ 73. doi:10.1016/0304-3878(83)90031-7

Fosu, A.K. (1990). Exports and economic growth: The African case. World Development, 18(6), 831835. doi:10.1016/0305-750x(90)90005-i

Furuoka, F. (2009). Econometric Analysis of the Export-led Growth Hypothesis: Evidence for BIMP-EAGA Countries. Philippine Journal of Development, 34(2), 25-42. Retrieved from https://pidswebs.pids.gov.ph/CDN/PUBLICATIONS/pidspjd07-2bimpeaga.pdf

Giles, J.A., \& Williams, C.L. (2000a). Export-led growth: a survey of the empirical literature and some noncausality results, Part 1. Journal of International Trade and Economic Development, 9(3), 261-337. https://doi.org/10.1080/09638190050086177

Giles, J.A., \& Williams, C.L. (2000b). Export-led growth: a survey of the empirical literature and some noncausality results, Part 2. Journal of International Trade and Economic Development, 9(4): 445-470. https://doi.org/10.1080/096381900750056867

Greenaway, D., \& Sapsford, D. (1994). What does liberalisation do for exports and growth. Weltwirtschaffliches Archiv, 130(1), 152-174. Retrieved from www.jstor.org/stable/40440270

Grossman, G.M., \& Helpman, E. (1991). Innovation and growth in the global economy. Cambridge: MIT Press. Retrieved from https://mitpress.mit.edu/books/innovation-and-growth-global-economy

He, D., \& Zhang, W. (2010). How dependent is the Chinese economy on exports and in what sense has its growth been export-led?. Journal of Asian Economics, 21, 87-104. Retrieved from https://ideas.repec.org/a/eee/asieco/v21y2010i1p87-104.html

Heller, P.S., \& Porter, R.C. (1978). Exports and growth. Journal of Development Economics, 5(2), 191 193. doi:10.1016/0304-3878(78)90007-x

Henriques, I., \& Sadorsky, P. (1996). Export-Led Growth or Growth-Driven Exports? The Canadian Case. The Canadian Journal of Economics / Revue Canadienne D'Economique, 29(3), 540-555. doi:10.2307/136249

Heitger, B. (1987). Import protection and export performance-Their impact on economic growth. Weltwirtschaftliches Archiv, 123(2), 249-261. doi:10.1007/bf02706662

Hye, Q.M., Wizarat, S., \& Wee-Yeap Lau, W.-P. (2013). Trade-led growth hypothesis: An empirical analysis of South Asian countries. Economic Modelling, 35, 654-660. https://doi.org/10.1016/j.econmod.2013.07.040

Im, K.S., Pesaran, M.H., \& Shin, Y. (2003). Testing for unit roots in heterogeneous panels. Journal of Econometrics, 115(1), 53-74. https://doi.org/10.1016/S0304-4076(03)00092-7

International Monetary Fund (2001). Global Trade Liberalization and the Developing Countries. Retrieved from https://www.imf.org/external/np/exr/ib/2001/110801.htm

Islam, M.N. (1998). Exports expansion and economic growth: Testing for Cointegration and Causality. Applied Economics, 30(3), 415-425. https://doi.org/10.1080/000368498325930 
Jin, J.C., \& Shih, Y.C. (1995). Export-led growth and the Four Little Dragons. Journal of International Trade and Economic Development, 4(2), 203-215. DOI:10.1080/09638199500000017

Jung, W.S., \& Marshall, P.J. (1985). Exports, growth and causality in developing countries. Journal of Development Economics, 18(1), 1-12. https://doi.org/10.1016/0304-3878(85)90002-1

Jesus, F.J., \& Lanzafame, M. (2020). The PRC's long-run growth through the lens of the export-led growth model. Journal of Comparative Economics, 48(1), 163-181. https://doi.org/10.1016/j.jce.2019.08.004

Kao, C. (1999). Spurious regression and residual-based tests for cointegration in panel data. Journal of Econometrics, 90(1), 1-44. https://doi.org/10.1016/S0304-4076(98)00023-2

Kao, C., \& Chiang, M.-H.. (2001). On the estimation and inference of a cointegrated regression in panel data. In B.H. Baltagi, T.B. Fomby, \& R. C. Hill, Nonstationary Panels, Panel Cointegration, and Dynamic Panels (Advances in Econometrics, Vol. 15) (pp. 179-222). Bingley: Emerald Group Publishing Limited.

Katz, B., \& Istrate, E. (2011). Boosting Exports, Delivering Jobs and Economic Growth. Project on State and Metropolitan Innovation, BROOKINGS-ROCKEFELLER. Retrieved from https://www.brookings.edu/wp-content/uploads/2016/06/0126_exports_katz_istrate.pdf

Kavoussi, R.M. (1984). Export expansion and economic growth. Journal of Development Economics, 14(1), 241250. doi:10.1016/0304-3878(84)90052-x

Keesing, D.B. (1967). Outward-looking policies and economic development. Economic Joumal, 77(306), 303320. https://doi.org/10.2307/2229306

Khan, A.H., \& Saqib, N. (1993). Exports and Economic Growth: The Pakistan Experience. International Economic Journal, 7(3), 53-63. https://doi.org/10.1080/10168739300080020

Kravis, I.B. (1970). Trade as a Handmaiden of Growth: Similarities Between the Nineteenth and Twentieth Centuries. The Economic Journal, 80(320), 850-872. doi:10.2307/2229902

Krueger, A.O. (1975). The Benefits and Costs of Import Substitution in India: A Microeconomic Study. Minneapolis: University of Minnesota Press. Retrieved from www.jstor.org/stable/10.5749/j.ctttsdwi

Krueger, A.O. (1978). Foreign Trade Regimes and Economic Development: Liberalization Attempts and Consequences. Boston: National Bureau of Economic Research, Inc. Retrieved from https://EconPapers.repec.org/RePEc:nbr:nberbk:krue78-1

Kugler, P. (1991). Growth, Exports and Cointegration: An Empirical Investigation. Weltwirtschaftliches Archiv, 127(1), 73-82. Retrieved from www.jstor.org/stable/40439969

Lee, F.-Y., \& Cole, W.E. (1994). Simultaneity in the study of exports and economic growth. International Economic Journal, 8(2): 33-41. Retireved from https://www.tandfonline.com/doi/abs/10.1080/10168739400000011

Leff, N.H. (1969). The "Exportable Surplus" Approach to Foreign Trade in Underdeveloped Countries. Economic Development and Cultural Change, 17(3), 346-355. doi:10.1086/450363

Love, J., \& Chandra, R. (2005). Testing export-led growth in South Asia. Journal of Economic Studies, 32(2), 132 145. https://doi.org/10.1108/01443580510600913

Lussier, M. (1993). Impacts of Exports on Economic Performance: A Comparative Study. Journal of African Economies, 2(1), 106-127. https://doi.org/10.1093/oxfordjournals.jae.a036768

Maizels, A. (1968). Exports and Economic Growth of Developing Countries. Cambridge: Cambridge University Press.

Mao, R., Yao, Y., \& and Zou, J. (2019). Productivity growth, fixed exchange rates, and export-led growth. China Economic Review, 56, 1-21. https://doi.org/10.1016/j.chieco.2019.101311

Michaely, M. (1977). Exports and growth. Journal of Development Economics, 4(1), 49-53. doi:10.1016/03043878(77)90006-2

Moschos, D. (1989). Export expansion, growth and the level of economic development. Journal of Development Economics, 30(1), 93-102. doi:10.1016/0304-3878(89)90052-7 
Pedroni, P. (1999). Critical values for cointegration tests in heterogeneous panels with multiple regressors. Oxford Bulletin of Economics and Statistics, 61(S1), 653-670. https://doi.org/10.1111/14680084.0610s1653

Pedroni, P. (2004). Panel cointegration: Asymptotic and finite sample properties of pooled time series tests with an application to the PPP hypothesis. Econometric Theory, 20(3), 597-625. https://doi.org/10.1017/S0266466604203073

Ram, R. (1985). Exports and Economic Growth: Some Additional Evidence. Economic Development and Cultural Change, 33(2), 415-425. Retrieved from www.jstor.org/stable/1153235

Ram, R. (1987). Exports and Economic Growth in Developing Countries: Evidence from Time-Series and Cross-Section Data. Economic Development and Cultural Change, 36(1), 51-72. doi:10.1086/451636

Harris, R.D., \& Tzavalis, E. (1999). Inference for unit roots in dynamic panels where the time dimension is fixed. Journal of Econometrics, $91(2), 201-226$. https:/ / doi.org/10.1016/S0304-4076(98)00076-1

Sengupta, J.K. (1991). Rapid Growth in NICs in Asia: Tests of New Growth Theory for Korea. Kyklos, 44(4), 561-580. https://doi.org/10.1111/j.1467-6435.1991.tb01797.x

Serletis, A. (1992). Export growth and Canadian economic development. Journal of Development Economics, $38(1)$ : 133-145. https://doi.org/10.1016/0304-3878(92)90022-2

Severn, A.K. (1968). Exports and Economic Growth. Kyklos, 21(3), 546-548. doi:10.1111/j.14676435.1968.tb00132.x

Shan, J., \& Sun, F. (1998). On the Export-Led Growth Hypothesis: The Econometric Evidence from China. Applied Economics, 30(8), 1055-1065. https://doi.org/10.1080/000368498325228

Sharma, A., \& Panagiotidis, T. (2005). An Analysis of Exports and Growth in India: Cointegration and Causality Evidence (1971-2001). Review of Development Economics, 9(2), 232-248. doi:10.1111/j.14679361.2005.00273.x

Sheehey, E.J. (1993). Exports as a factor of production: A consistency test. World Development, 21(1), 155-160. https://doi.org/10.1016/0305-750X(93)90143-W

Singh, T. (2010). Does International Trade Cause Economic Growth? A Survey. World Economy, 33(11), 15171564. https://doi.org/10.1111/j.1467-9701.2010.01243.x

Srinivasan, T.N. (1985). Neoclassical political economy, the state and economic development. Asian development review, 3(2), 38-58.

Syron, R.F., \& Walsh, B.M. (1968). The Relation of Exports and Economic Growth. Kyklos, 21(3), 541-545. doi:10.1111/j.1467-6435.1968.tb00131.x

Tang, C.F., Lai, Y.W., \& Ozturk, I. (2015). How stable is the export-led growth hypothesis? Evidence from Asia's Four Little Dragons. Economic Modelling, 44, 229-235. https://doi.org/10.1016/j.econmod.2014.09.022

Tang, C.F., \& Tan, E.C. (2015). The Relative Contributions of Domestic and Foreign Direct Investments and Exports to Malaysia's Economic Growth. The Singapore Economic Review, 60(2), 1550011. https://doi.org/10.1142/S0217590815500113

Tang, C.F., \& Abosedra, S. (2019). Logistics performance, exports, and growth: Evidence from Asian economies. Research in Transportation Economics, 78, 100743. https://doi.org/10.1016/j.retrec.2019.100743

Tiwari, A.K. (2011). Tourism, Exports and FDI as a Means of Growth: Evidence from four Asian Countries. Romanian Economic Journal, 14(40), 131-151. Retrieved from https://www.researchgate.net/publication/227348951

Tyler, W.G. (1981). Growth and export expansion in developing countries. Journal of Development Economics, 9(1), 121-130. doi:10.1016/0304-3878(81)90007-9 
Van den Berg, H., \& Schmidt, J.R. (1994). Foreign trade and economic growth: Time series evidence from Latin America. Journal of International Trade and Economic Development, 3(3), 121-130. doi:10.1080/09638199400000016

Westerlund, J. (2005). New Simple Tests for Panel Cointegration. Econometric Reviews, 24(3), 297-316. https://doi.org/10.1080/07474930500243019

World Bank. (2018). Stronger Open Trade Policies Enable Economic Growth for All. Retrieved from https://www.worldbank.org/en/results/2018/04/03/stronger-open-trade-policies-enableseconomic-growth-for-all

World Trade Organization (2021). WTO in Brief. Retrieved from https://www.wto.org/english/thewto_e/whatis_e/inbrief_e/inbr_e.pdf 


\section{APPENDIX: LIST OF 107 COUNTRIES USED IN ANALYSIS}

\begin{tabular}{|c|c|c|c|c|}
\hline Argentina & Colombia & Indonesia & Mozambique & Sierra Leone \\
\hline Australia & Comoros & India & Mauritania & El Salvador \\
\hline Austria & Costa Rica & Ireland & Mauritius & Slovenia \\
\hline Belgium & Cuba & Iran, Islamic Rep. & Malaysia & Sweden \\
\hline Benin & Cyprus & Iceland & Namibia & Eswatini \\
\hline Burkina Faso & Czech Republic & Israel & Nigeria & Togo \\
\hline Bangladesh & Germany & Italy & Nicaragua & Thailand \\
\hline Bulgaria & Denmark & Jordan & Netherlands & Tunisia \\
\hline Bahamas, The & Dominican Republic & Japan & Norway & Turkey \\
\hline Belarus & Algeria & Kazakhstan & New Zealand & Tanzania \\
\hline Belize & Ecuador & Kenya & Pakistan & Uganda \\
\hline Bolivia & Egypt, Arab Rep. & Korea, Rep. & Panama & Ukraine \\
\hline Brazil & Spain & Lebanon & Peru & Uruguay \\
\hline Brunei Darussalam & Finland & Sri Lanka & Philippines & United States \\
\hline Botswana & France & Lesotho & Portugal & Venezuela, RB \\
\hline Canada & Gabon & Luxembourg & Paraguay & Vietnam \\
\hline Switzerland & United Kingdom & Macao SAR, China & Romania & South Africa \\
\hline Chile & Greece & Morocco & Russian Federation & Zambia \\
\hline China & Guatemala & Madagascar & Rwanda & Zimbabwe \\
\hline Cameroon & Hong Kong SAR, China & Mexico & Sudan & \\
\hline Congo, Dem. Rep. & Honduras & North Macedonia & Senegal & \\
\hline Congo, Rep. & Haiti & Mali & Singapore & \\
\hline
\end{tabular}

